IFN Working Paper No. 863, 2011

\title{
Intangible Investment and the Swedish Manufacturing and Service Sector Paradox
}

Harald Edquist 


\title{
Intangible Investment and the Swedish Manufacturing and Service Sector Paradox
}

\author{
by \\ Harald Edquist $^{\dagger}$
}

2011-04-10

\begin{abstract}
Since the mid 1990s labor productivity growth in Sweden has been high compared to Japan, the US and the western EU-countries. While productivity growth has been rapid in manufacturing, it has been much slower in the service sector. Paradoxically, all employment growth since the mid 1990s has been created in business services. The two traditional explanations of this pattern are Baumol's disease and outsourcing. This paper puts forward an additional explanation, based on the observation that manufacturing industries have invested heavily in intangible assets such as R\&D and vocational training. In 2005-2006, intangible investment was 25 percent of value added in manufacturing, while the corresponding figure for the service sector was 11 percent. Moreover, calculations based on the growth accounting framework at the industry level in 2000-2006 show that intangible investment accounted for almost 30 percent of labor productivity growth in manufacturing. Thus, investments in intangibles that mostly are knowledge intensive services have contributed considerable to productivity growth in Swedish manufacturing since 1995.
\end{abstract}

JEL Classifications: O14; O32; O33

Keywords: Intangibles; Manufacturing, Productivity growth; Service sector; Sector analysis

\footnotetext{
* I am grateful for useful comments from Jonathan Haskel, Henrik Jordahl, Annarosa Pesole and participants at COINVEST seminar in London. Financial Support from the European Commission is also gratefully acknowledged.

${ }^{\dagger}$ Research Institute of Industrial Economics (IFN), Box 55665, SE-102 15 Stockholm, Sweden, E-mail: Harald.Edquist@ifn.se
} 


\section{Introduction}

Since the mid 1990s Sweden has had one of the highest labor productivity growth rates among western countries. Productivity growth has been particularly rapid in Swedish manufacturing, while it has been considerably slower in business services. Figure 1 shows annual labor productivity growth in manufacturing and business services for EU-15, Japan and the US in 1995-2007. According to figure 1, annual productivity growth in Swedish manufacturing was the second highest among the included countries at 6.6 percent 1995 2007. The productivity growth in business services was only 2.3 percent per year and lower relative to a number of other countries.

Despite the strong productivity performance in Swedish manufacturing employment growth has been negative in this sector. Thus, all employment growth in the business sector since the mid 1990s has been created in services. Paradoxically, the service sector has become more important for economic development despite its poor productivity performance in comparison with manufacturing. Two possible explanations are Baumol's disease and outsourcing. Baumol (1967) argued that there would be less job opportunities in manufacturing due to higher productivity growth in this sector compared to services. New job opportunities would instead be created in the service sector. Slower productivity growth in services would imply increasing relative prices of services over time. Alternatively, the productivity pattern could be explained by outsourcing. This could be the case if there has been an increased specialization in manufacturing so that services that used to be produced by manufacturing firms are instead produced by firms specialized in services (Svensson 2010).

This paper shows that an additional explanation to the paradox is that manufacturing companies have invested considerably in intangible assets since 1995. The intangible investments mostly consist of knowledge intensive services and are produced both within manufacturing and by service sector firms. The results in the paper show that these investments have contributed considerably to productivity growth in Swedish manufacturing.

Most intangibles are not capitalized in the National Accounts which means that they are identified as intermediate expenses rather than as investment and are therefore not included in GDP figures. A growing literature has been trying to estimate the magnitudes and effects of intangible investment in a number of different countries (see Corrado, Hulten and Sichel 
2005; 2006; 2009; Edquist 2011; Fukao, Miyagawa, Mukai, Shinoda and Tonogi 2009; Hao, Manole and van Ark 2009; Marrano and Haskel 2006; Marrano, Haskel and Wallace 2009). The results suggest that intangible investment accounts for substantial shares of GDP in many European countries, Japan and the US. Moreover, calculations based on the growth accounting framework have shown that investment in intangibles also accounts for a large share of labor productivity growth in these countries. In Sweden, investments in intangibles were almost 10 percent of GDP and accounted for nearly 30 percent of labor productivity growth in the business sector 1995-2006 (Edquist 2011).

Many intangibles consist of knowledge-intensive services. Thus, it is possible to argue that investment in services have been important for economic and productivity growth during the last decades in many industrialized countries. However, since most studies so far have focused on the impact of intangibles at the country or business sector level, it has not been investigated thoroughly how important intangible investments are for specific industries. This paper investigates how important intangible investment is in different sectors of the Swedish economy with a specific focus on manufacturing and services. More specifically the following questions will be addressed:

- How large were intangible investments in Swedish manufacturing and services?

- How large were intangible investments in Swedish manufacturing and services compared to other countries?

- How much of labor productivity growth did intangible capital account for in different industries?

\section{Data on intangibles at the sector level}

This paper follows the methodological framework set up by Corrado et al. (2006; 2009). They distinguish between three major categories of intangible assets: i) computerized information; ii) innovative property and iii) economic competencies. Each of these categories comprises different subcategories of intangibles that are listed in table 1. Various methods and surveys are used to estimate the spending on such assets for the years 1995-2006, the specifics of which are described in section 2.1-2.3. 


\subsection{Computerized information}

Computer information comprises computer software and computerized databases, both purchased and own-account. The estimates for computer software stem from EU KLEMS (2009), a database suitable for studying industry level productivity in the European Union. Investment is measured by nominal gross fixed capital formation (GFCF) in software for Sweden during the years between 1995 and 2006. Spending on computerized databases is already included in the estimates of software spending provided by the EU KLEMS (2009).

\subsection{Innovative property}

Innovative property includes a number of sub-categories i.e. research and development (R\&D), mineral explorations, copyright and license cost, development cost in financial services, and design.

\subsubsection{Research and development ( $R \& D$ )}

R\&D data at the industry level for Sweden is derived from the ANBERD database (OECD 2009). R\&D should include an appreciable element of novelty and involve the resolution of scientific and technological uncertainty (Frescati Manual 2002). R\&D data for mining is not available in the ANBERD database. Therefore, the R\&D estimates for mining are based on data from Statistics Sweden. ${ }^{1}$ Moreover, for some years there are missing values for a few service sectors. It it is therefore assumed that the spending on $R \& D$ in these services is the average ratio of the spending to total business sector for the years where estimates are available for each specific service sector. ${ }^{2}$

\subsubsection{Mineral explorations}

Mineral exploration is based on data from the Geological Survey of Sweden. It primarily covers the prospecting of new ore deposits with the expectation of future returns (as opposed to expenditure on ore-mining to extract existing ore deposits). Since the activity is only carried out in the mining sector a breakdown by industry is not provided.

\footnotetext{
${ }^{1}$ Data for the mining industry is only available for every other year. The missing values are estimated as the average share of R\&D spending in mining relative to total manufacturing for the year after and before the missing value.

${ }^{2}$ This implies that the aggregate value for R\&D spending for the total business sector is slightly different from the R\&D estimates used in Edquist (2011). Moreover, in Edquist (2011) total R\&D spending was deducted with the R\&D spending on computer and related activities in order to avoid double counting. In this paper R\&D spending on computer and related activities are not excluded.
} 


\subsubsection{Copyright and license cost}

Copyright and license cost is measured as investment in entertainment, literacy and artistic originals in the GFCF accounts in 1995-2006. These figures cover literacy, musical works and the production of film and certain TV and radio programmes. However, to be included they must be covered by copyright, have primary artistic intent, meet the capitalization criterion of use for more than one year and not be accounted for anywhere else in the national accounts. $^{3}$

Most of the entertainment, literacy and artistic originals are produced within other community and social services (ISIC 90-95). ${ }^{4}$ Since this industry is excluded from the non-farm business sector (see section 4.1) only the entertainment, literacy and artistic originals produces by prepress activities (ISIC 2224) will be included.

\subsubsection{Development cost in financial services}

Corrado et al. (2006) measured product development in the financial services industry, assuming it to be 20 percent of total intermediate spending. This paper follows their method and uses a measure of intermediate input for financial intermediation (ISIC 65) and activities related to financial intermediation (ISIC 67). ${ }^{5}$ The source of the intermediate spending is EU KLEMS (2008; 2009). All development cost in financial services is assumed to be carried out within this industry itself.

\subsubsection{Design}

Design has been measured both as a purchased component and an own-account component. The purchased component is estimated based on the turnover of architectural and engineering activities (ISIC 742) weighted with the number of employees in the industry that has a design occupation. ${ }^{6}$ Thus the spending on purchased design activities can be written: ${ }^{7}$

\footnotetext{
${ }^{3}$ The GFCF accounts are based on what is paid from clients to the originators. For literature and music the estimates are based on current payments under copyrights and other payments such as royalties. Revenues from Swedish cinema are recorded as annual revenue, without payment of compensation under the copyright.

${ }^{4}$ ISIC stands for International Standard Industrial Classification and has been developed by the United Nations. In this paper the third revision of ISIC is used.

${ }^{5}$ The purchase of other intangibles that are counted elsewhere (i.e. software, consultancy services, architectural and engineering services and advertising) is subtracted from intermediate inputs.

${ }^{6}$ Based on Galindo-Rueda et al. (2008), the following occupations have been defined as design occupations: architects and town planners (SSYK 2141), civil engineers (SSYK 2142), electrical engineers (SSYK 2143), electronics and telecommunications engineers (SSYK 2144), mechanical engineers (SSYK 2145), chemical engineers (SSYK 2146), designers (SSYK 2456) and decorators and commercial designers (SSYK 3471).
} 
Where, $Y_{p}$ is the measured purchased architectural and engineering design (AED) output, $Y^{742}$ is the output of ISIC 742 and $N^{742 A E D}$ is the number of employees with design occupations in ISIC 742 and $N^{742}$ is the number of employees in ISIC 742. Purchased design in different sectors is estimated based on use table for the product group architectural and engineering activities (SPIN 742) for different industries in 2005.

Own account design output is the design produced within firms in other sectors than architectural and engineering activities (ISIC 742). For example the Swedish car manufacturer Volvo spends considerable amounts on design of cars, which is produced by designers employed at Volvo. These design services never result in market transactions.

To estimate the own account component, we divide purchased AED $\left(Y_{p}\right)$ with the wage bill of designers in ISIC $742\left(w N^{742 A E D}\right)$. Thus, a ratio indicating the output per invested wage unit in ISIC 742 is obtained. It is then assumed that each invested wage unit is the same for persons with design occupations both working within SIC 742 and outside. This implies that by multiplying the ratio $Y_{p} / w N^{742 A E D}$ with the wage bill of persons with design occupations not working in SIC $742\left(w N^{B A E D}\right.$ ) we obtain the own account output. This can be expressed in the following formula:

$Y_{\text {own }}=\frac{Y_{p}}{w N^{742 A E D}} w N^{B A E D}$

where $Y_{\text {own }}$ is the own account output, $Y_{p}$ the purchased output. ${ }^{8}$ Estimates of wage sums of people with design occupations in different industries in 2007 are used to estimate own account spending in different industries.

\footnotetext{
${ }^{7}$ For some engineering occupations, it is likely that the employees to some extent are also involved in R\&D activities which then implies double counting. Therefore only 50 percent of the spending of design is considered as investment (see section 3).

${ }^{8}$ Data for all variables in equation 1 and 2 is available for the period 1997-2007. For the period 1993-96 the wage bill has been estimated based on the average ratio of wage bill/turnover for the years 1997-2007. Moreover, data on the number of persons employed in ISIC 742 1993-96 are based on the average ratio of employment in ISIC 742 and total employment in 1997-2007.
} 


\subsection{Economic competencies}

Economic competencies include three different sub-categories, i.e. brand equity, vocational training and organizational structure.

\subsubsection{Brand equity}

Brand equity is measured as two components, namely advertising and market research.

\subsubsection{Advertising}

Data on spending on advertising comes from the Swedish Institute for Advertisement (IRM). Classified ads and the government sector were deducted from the total spending. ${ }^{9}$ Use tables for advertisement (SPIN 744) based on the year 2005 were used to investigate the spending by specific industries.

\subsubsection{Market research}

Market research is estimated as twice the turnover of the market and consumer research industry (ISIC 7413). It is assumed that own account market research equals purchased market research. Use tables for business consultancy (SPIN 741) for the year 2005 were used to estimate the spending by specific industries.

\subsubsection{Vocational training}

The vocational training is based on a survey of employer provided training conducted by Statistics Sweden in 1999 (CVTS 1999). Data on vocational training is available for 20 different industries. CVTS (1999) measures the direct and indirect costs of continuing vocational training in firms with at least 10 employees as a percentage of total labor costs in 1999. It is assumed that firms with less than 10 employees spend the same proportion of their total labor costs on vocational training. Moreover, it is assumed that the proportion of labor costs spent by firms in 1995-2006 is the same as in 1999. Finally, to measure the total spending by all firms in each industry it is assumed that the proportion of the spending on vocational training is the same for all industries as in 1999.

\footnotetext{
${ }^{9}$ Data on classified ads were deducted based on figures for 2007, when classified ads accounted for approximately 8 percent of total advertisement and 35 percent of the advertisement in newspapers. According to a survey by SIFO Research International, the government sector answered for approximately 1.1 percent of total spending on advertisement. Hence, it is assumed that this share is the same for the period 1995-2007.
} 


\subsubsection{Organizational structure}

Investment in organizational structure includes a purchased component and an own-account component.

\subsubsection{Purchased organizational structure}

Purchased organizational structure is measured as the turnover of business and management consultancy activities (ISIC 7414). The turnover has been adjusted so that only products that include services that affect organizational structure are included. ${ }^{10}$ Moreover, the share of the turnover purchased by the public sector is excluded based on data from the Swedish business magazine Affärsvärlden (2001-2004). ${ }^{11}$ Use tables for business consultancy services (SPIN 741) in 2005 are used to estimate spending in different industries.

\subsubsection{Own-account organizational structure}

The own account spending is measured as 20 percent of managers' income following the assumption that managers spend 20 percent of their time on organizational structuring. The breakdown at the industry level is based on the share of the total wages earned by managers in different sectors. The sector data is for the year 2008 and provided by Statistics Sweden.

\section{How much of the spending is investment}

According to Corrado et al. (2005, 2009) and Marrano et al. (2009), not all spending on intangibles can be considered as investment. It is necessary to separate the expense of current production from outlays that expand future productive capacity. For physical capital, this distinction is often made on the basis of the durability or expected service life of a purchase. Yet the service life of a specific asset can at times be ambiguous. The Bureau of Economic Analysis (BEA) estimates that business fixed assets have a useful service life of at least three years, while other studies define business sector equipment as having a service life of more than one year.

\footnotetext{
${ }^{10}$ The following services are assumed to affect organizational structure: advise regarding distribution, employees, mergers and acquisition, organizations, taxes, marketing, production, project leadership and administration. It has only been possible to estimate the share of these services for the year 2006; the same share is therefore used to estimate purchased organizational structure for other years.

${ }^{11}$ It is assumed that the share of turnover purchased by the public sector is the same for the period 1995-2000 and 2005-06 as the average share for the period 2001-2004.
} 
Based on this logic, Corrado et al. (2005) assume that the proportion of spending that can be considered as investment can be approximated as follows:

1. If economic research has clearly shown that a given type of spending is fixed investment, then 100 percent is classified as capital investment.

2. If economic research suggests only a portion of the spending on an intangible pays off in future year (or years), these findings are applied.

3. When there is strong suspicion that the lifetime of a type of intangible may not be at least three years, the item is discounted by 20 percent and a range of estimates of capital investment is shown for the item.

4. When there is strong suspicion that a portion of the spending may be for routine tasks or represent current consumption, the point estimate is discounted by 20 percent.

Table 1 shows the proportion of spending considered as investment according to the approximation used by Corrado et al. (2005). Little is known about the service life of software, yet the BEA assumes a three year service life for all prepackaged software and a five year service life for custom and own-account software. Therefore Corrado et al. (2006) assume 100 percent of total spending on computerized information should be classified as capital investment. The same rule applies for scientific R\&D spending, mineral exploration, copyright and license cost and development costs in financial services.

Based on estimates provided by Gallindo-Rueda et al. (2008), only 50 percent of design spending should be counted as investment. Economic research on marketing has found that the effects of advertising are generally short lived. However, according to Landes and Rosenfield (1994) more than half of the expenditure on advertising has a service life of at least one year and one-third has an impact of more than three years. Thus, Corrado et al. (2005) estimate that approximately 60 percent of total advertising expenditures have longlasting effects. In addition, continuing vocational training has long lived effects and is therefore counted as investment. While spending on organizational change also has likely long-lived effects, only 80 percent is considered as investment because a portion of purchased management expertise comprises rather routine tasks.

It is evident that in many cases the process of estimating the share of spending that actually is investment is not very precise. Nevertheless, an attempt to measure investment in intangibles 
must use the best available information. Importantly, service life is at least 3 years for some of the larger types of intangibles like scientific R\&D and vocational training, implying that 100 percent of the spending should be counted as investment.

\section{Measures of intangible investment}

\subsection{Definition of the business sector}

In the Swedish National Accounts the business sector is defined as market producers and producers of own final goods in industries ISIC 01-95. Hence, the public sector is excluded. Moreover, in this paper agriculture, forestry and fishing (ISIC 01-05), educational, health and social work (ISIC 80-85) and other community and personal services (ISIC 90-95) are excluded from the business sector. This implies that the business sector is defined as ISIC 1074.

Table 2 shows the industry breakdown that will be used throughout the paper. Investment in intangibles is measured for 5 different industries in the non-farm business sector. These are as follow: Mining (ISIC 10-14), manufacturing (ISIC 15-37), electricity (ISIC 40-41), construction (ISIC 45) and business services (ISIC 50-74).

\subsection{Total business sector}

Figure 2 shows that the spending on intangible assets in the total business sector was approximately 12 percent of GDP in 2006. Based on the methods described in section 3, the total investment in intangibles is estimated to be 274 billion SEK or 10 percent of GDP. The Swedish investment in fixed capital for the business sector in 2006 was 376 billion SEK or 13 percent of GDP. ${ }^{12}$ Hence, the estimated investment in intangibles was approximately 75 percent of the investment in physical capital.

It is also interesting to note that in 1960, investment in physical capital in the Swedish business sector came to 22 percent of GDP. Investment in physical capital has thus decreased considerably in the Swedish business sector since 1960. However, if investment in intangible

\footnotetext{
${ }^{12}$ Investments in software and copyright and license costs were subtracted from fixed capital since they are defined as intangible investments.
} 
capital is added to physical capital, total investment reaches the figure of 22 percent of GDP. There are no estimates available for intangible capital in 1960, but it is likely that investment in intangibles was much lower in 1960 compared to 2006. Thus, it is not necessarily true that investment in the Swedish economy has decreased quite rapidly, as many economists have argued (SOU 2000:11). It is more likely that the structure of the Swedish economy has become more service-based.

\subsection{Measures for manufacturing and services}

\subsubsection{Measures for Sweden}

According to the previous section, intangible investment has been substantial and accounted for as much as 10 percent of GDP in the Swedish business sector in 2006 . While most tangible assets are machines and buildings, most intangibles are services. Nevertheless, both tangible and intangible assets are used in manufacturing and the service sector. Is it then manufacturing or the service sector that have made the largest investment in intangibles?

Table 2 shows investment in tangible and intangible assets in the Swedish business sector in 2006 in absolute and relative figures. Manufacturing accounted for 18 percent of total investment in tangible assets while it accounted for as much as 47 percent of total investment in intangibles. Business services (ISIC 50-74) accounted for 67 percent of the total investment in tangible capital, while it accounted for 48 percent of the investment in intangible capital. Thus, the service sector invested more than manufacturing in terms of tangible assets, while intangible investments were approximately the same in the two different sectors. It is also interesting that intangible investment was more than twice as large as compared to tangible investment in manufacturing.

Figure 3 shows the ratio of intangible investment to tangible investment in manufacturing and services 1995-2006. Since the mid 1990s the ratio has almost doubled in manufacturing while it has stayed approximately the same in the service sector. According to figure 3 intangible investment has increased relative to tangible investment in manufacturing since 1995. Thus, there is strong indication of a structural shift in manufacturing with intangibles becoming increasingly important in manufacturing production. In the service sector, tangible and intangible investment increased at the same pace. 
Figure 4 shows the investment in different categories of intangibles for manufacturing and the service sector in 2006. According to figure 3 the largest investment in intangibles was for R\&D with almost 80 billion SEK. Manufacturing accounted for approximately 80 percent of the total investment in R\&D. The second largest investment was in software with a total investment of 55 billion SEK. However, services accounted for almost 70 percent of the total investment in software.

Large intangible investment was also found for organizational structure, design, brand equity and vocational training, while intangible investments were small in financial development, copyright and license and mineral exploration. In all categories except R\&D, investments were larger in the service sector than in manufacturing. Thus, manufacturing was very intensive in $R \& D$, while the service sector accounted for most of the intangible investment in other categories.

\subsubsection{Comparisons with other countries}

It is of great interest to compare the Swedish estimates of intangible investment in manufacturing and services with other countries. Estimates of intangibles at the industry level have only been published for a few countries. Figure 5 compares intangible investment for Australia, Japan, the Netherlands, Sweden and the UK in manufacturing and services.

In absolute numbers, investments were larger in services than in manufacturing in all countries. However, figure 5 shows that in relation to the value added of each sector intangible investments were larger in manufacturing in all countries. Moreover, the relative differences between countries were considerable. In Sweden, intangible investment in manufacturing was 25 percent of the total value added in this sector, while the corresponding figure for the service sector was 10 percent. This shows that even though intangible investment was approximately the same in Swedish manufacturing and services in absolute numbers, it was considerably larger in manufacturing in relative terms.

Intangible investment as a share of value added in manufacturing was also large in the UK and Japan, with 21 and 18 percent, respectively. Intangible investments in manufacturing were considerably lower in Australia and the Netherlands. For the service sector intangible investments as a share of value added in services were larger in the UK and the Netherlands 
than in Sweden. However, the differences in intangible investments by the service sectors were much smaller between all countries given the relative size of the service sector.

\section{Growth accounting methodology}

In section 4.2.1 it was shown that intangible investment has increased considerably in manufacturing. An interesting question is then how much of the productivity growth in manufacturing intangible capital would account for if the growth accounting methodology (Solow 1957) was used at the industry level.

\subsection{Total economy}

This paper follows the model designed by Corrado et al. (2006). It assumes three sectors and three different goods produced: a consumption good, with real output volume $C_{t}$ and price $P_{t}^{C}$ ; a tangible investment good, $I_{t}$ with price $P_{t}^{I}$; and an intangible investment good, $N_{t}$ with price $P_{t}^{N}$; where the subscript denotes time.

Based on the perpetual inventory method the tangible capital stock accumulates according to:

$$
K_{t}=I_{t}+\left(1-\delta_{K}\right) K_{t-1}
$$

Where $\delta_{K}$ is the depreciation rate, $K_{\mathrm{t}}$ is the real stock of tangible capital and $I_{\mathrm{t}}$ investment in tangible capital. The intangible capital stock is given by $R_{\mathrm{t}}$ which accumulates according to:

$$
R_{t}=N_{t}+\left(1-\delta_{R}\right) R_{t-1}
$$

Where $N_{\mathrm{t}}$ is investment in intangible capital.

Based on the assumptions that factors are paid their marginal product and the production function is homogenous of degree 1 , all sectors rent tangible and intangible capital so that their production functions and money flows can be written:

(a) Intangible investment good producing sector:

$$
N_{t}=F^{N}\left(L_{N, t,} K_{N, t}, R_{N, t}, t\right) ; P_{t}^{N} N_{t}=P_{t}^{L} L_{N, t}+P_{t}^{K} K_{N, t}+P_{t}^{R} R_{N, t}
$$


(b) Tangible investment good producing sector:

$I_{t}=F^{I}\left(L_{I, t}, K_{I, t}, R_{I, t}, t\right) ; P_{t}^{I} I_{t}=P_{t}^{L} L_{I, t}+P_{t}^{K} K_{I, t}+P_{t}^{R} R_{I, t}$

(c) Consumption good producing sector:

$C_{t}=F^{C}\left(L_{C, t}, K_{C, t}, R_{C, t}, t\right) ; P_{t}^{C} C_{t}=P_{t}^{L} L_{C, t}+P_{t}^{K} K_{C, t}+P_{t}^{R} R_{C, t}$

The stock of intangible capital, $R_{t}$ appears as an input in the production functions and the payment to that stock; in addition, $P_{t}^{R} R_{t}$, appears in the payment equations. It is then possible to write nominal GDP as follows:

$P_{t}^{V} V_{t}=P_{t}^{C} C_{t}+P_{t}^{I} I_{t}+P_{t}^{N} N_{t}=P_{t}^{L} L_{t}+P_{t}^{K} K_{t}+P_{t}^{R} R_{t}$

Real aggregate value added growth (GDP) then becomes:

$\Delta \ln V_{t}=s_{t}^{L} \Delta \ln L_{t}+s_{t}^{K} \Delta \ln K_{t}+s_{t}^{R} \Delta \ln R_{t}+\Delta \ln T F P_{t}$

$S^{x}=\left(P^{x} X / P^{V} V\right) \quad X=K, L, R$

The equations show that the effect of including intangibles on growth is ambiguous, depending on the growth rate of real intangible investment. The $s^{x}$ terms are the input factor shares. $^{13}$

\subsection{Industry level}

According to Clayton et al. (2009) if we assume that capital and labor are paid the same across industries then we have the following industry and aggregate variables:

$\Delta \ln K=\sum_{k} \bar{w}_{k} \Delta \ln K_{k}$, capital type $\mathrm{k}$

$\Delta \ln R=\sum_{r} \bar{w}_{r} \Delta \ln R_{r}$, capital type $\mathrm{r}$

$\Delta \ln L=\sum_{l} \bar{w}_{l} \Delta \ln L_{l}$, labor type l

$\bar{w}_{k}=P_{K, k} K_{k} / \sum_{k}\left(P_{K, k} K_{k}\right)$

\footnotetext{
${ }^{13}$ For a decomposition of labor productivity growth, estimation of capital services and assumptions about depreciation rates and deflators see Edquist (2011).
} 


$$
\begin{aligned}
& \bar{w}_{r}=P_{R, r} R_{r} / \sum_{r}\left(P_{R, r} R_{r}\right) \\
& \bar{w}_{l}=P_{L, l} L_{l} / \sum_{l}\left(P_{L, l} L_{l}\right) \\
& K_{j}=\sum_{j} K_{k, j} \forall k \\
& R_{j}=\sum_{j} R_{r, j} \forall r \\
& L_{j}=\sum_{j} L_{l, j} \forall l \\
& \bar{w}_{t}=0.5\left(w_{t}+w_{t-1}\right)
\end{aligned}
$$

Where $j$ denotes industry. The definition of real aggregate value added depends on the assumptions one makes about value added at the industry level. In this paper we assume a production possibility frontier in accordance with Jorgenson, Ho and Stiroh (2007). This implies that the price deflator of value added is no longer the same across industries and it is therefore not possible to simply sum industry value added. However it is still assumed that inputs are paid the same price across industries. Aggregate value added is defined from the production possibility frontier as:

$$
\begin{aligned}
& \Delta \ln V=\sum_{j} \bar{w}_{j} \Delta \ln V_{j} \\
& w_{j}=\frac{P_{v, j} V_{j}}{\sum_{j} P_{v, j} V_{j}} \\
& \bar{w}_{j}=0.5\left(w_{j, t}+w_{j, t-1}\right)
\end{aligned}
$$

Where $P_{v, j}$ is the price deflator of value added in industry $j$.

Gross output growth at the industry level is defined as the contribution of labor $\left(L_{j}\right)$, contribution of tangible capital $\left(K_{j}\right)$, contribution of intangible capital $\left(R_{j}\right)$, contribution of intermediate inputs $\left(X_{j}\right)$ and TFP, all for industry $j$. The growth rates of the four are weighted by their share in gross output.

$$
\Delta \ln Y_{j}=\bar{v}_{L, j} \Delta \ln L_{j}+\bar{v}_{K, j} \Delta \ln K_{j}+\bar{v}_{R, j} \Delta \ln R_{j}+\bar{v}_{X, j} \Delta \ln X_{j}+\Delta \ln T F P_{j}
$$


This implies that industry output is:

$\Delta \ln Y_{j}=\bar{v}_{V, j} \Delta \ln V_{j}+\bar{v}_{X, j} \Delta \ln X_{j}$

where $V_{j}$ is the value added in industry $j$ and $\bar{v}_{V, j}$ is the share of value added in industry gross output and $X_{j}$ is intermediate inputs and $\bar{v}_{X, j}$ is the share of intermediate inputs in gross output.

By rearranging equation (27) and (28) we get:

$\Delta \ln V_{j}=\frac{\bar{v}_{L, j}}{\bar{v}_{V, j}} \Delta \ln L_{j}+\frac{\bar{v}_{K, j}}{\bar{v}_{V, j}} \Delta \ln K_{j}+\frac{\bar{v}_{R, j}}{\bar{v}_{V, j}} \Delta \ln R_{j}+\frac{1}{\bar{v}_{V, j}} \Delta \ln T F P_{j}$

Based on the definition of aggregate output from the production possibility frontier in equations (24) to (26) it is possible to write the aggregate value added growth in the following way:

$\Delta \ln V=\sum_{j} \bar{w}_{j} \Delta \ln V_{j}=\sum_{j} \bar{w}_{j} \frac{\bar{v}_{L, j}}{\bar{v}_{V, j}} \Delta \ln L_{j}+\sum_{j} \bar{w}_{j} \frac{\bar{v}_{K, j}}{\bar{v}_{V, j}} \Delta \ln K_{j}+\sum_{j} \bar{w}_{j} \frac{\overline{\bar{v}}_{R, j}}{\bar{v}_{V, j}} \Delta \ln R_{j}+\bar{w}_{j} \frac{1}{\bar{v}_{V, j}} \Delta \ln T F P_{j}$

Equation (30) shows that aggregate value added growth reflects the weighted contribution of labor input, tangible capital input, intangible capital input and TFP. According to Jorgenson et al. (2007) the weights on capital and labor reflect three factors: the relative size of industry value added in aggregate value added $\left(\bar{w}_{j}\right)$, tangible capital, intangible capital or labor income in industry $j$ as a share of gross output $\left(\bar{v}_{L, j}, \bar{v}_{K, j}\right.$ and $\left.\bar{v}_{R, j}\right)$ and the share of industry value added in industry gross output $\left(\bar{v}_{V, j}\right)$. The weights on industry TFP reflect the relative size of industry value added in aggregate value added $\left(\bar{w}_{j}\right)$ and the share of industry value added in industry gross output $\left(\bar{v}_{V, j}\right)$.

\section{Growth accounting results}

\subsection{Total business sector}

Figure 6 shows the results when the growth accounting framework is applied for the total business sector including and excluding intangible capital in 1995-2006. According to figure 
6 annual labor productivity growth is 3.8 percent when intangible capital is excluded. Tangible capital accounts for 1.6 percentage points. Labor quality accounts for 0.3 percentage points, while TFP accounts for 1.9 percentage points.

When intangible capital is included, labor productivity growth increases slightly to 4.0 percent. The other inputs all accounts for slightly smaller shares, while intangible capital accounts for 1.2 percentage points of the growth rate and thus 31 percent of the total labor productivity growth. TFP accounts for 1.2 percentage points of the productivity growth when intangibles are included. Thus, the TFP component decreases radically in both economic and labor productivity growth. According to Edquist (2011) no other country investigated so far exhibits such a large effect on TFP when intangibles are included in the growth accounting framework as does Sweden. Consequently, increased investment in intangible assets explains a large share of the unexplained labor productivity growth in the Swedish business sector.

\subsection{Results for the industry level growth accounting}

Tables 3 and 4 show the results when growth accounting is used at the industry level for 5 different industries including and excluding intangible assets for the period 2000-2006. According to table 3 annual labor productivity growth is highest in manufacturing with 4.6 percent when intangible capital is excluded. ${ }^{14}$ Labor productivity in business services is 3.0 percent, while lowest productivity growth was found for electricity, gas and water.

The contribution from tangible capital deepening is largest in Mining with 1.7 percentage points. The corresponding figures for manufacturing and business services are 0.4 and 0.7 percentage points. Thus, tangible capital deepening accounts for 9 percent of labor productivity growth in manufacturing and 22 percent in business services. Intermediate inputs deepening has largest impact in manufacturing with 2.6 percentage points or nearly 58 percent of labor productivity growth. Finally, TFP is highest in manufacturing with 1.4 percentage points compared to 0.8 percentage points in business services.

When intangible capital is included in the growth accounting framework annual labor productivity growth remains highest in manufacturing with 4.2 percentage points, while it

\footnotetext{
${ }^{14}$ Labor productivity at the industry level is defined as gross output per hour worked (see equation 27).
} 
remains 3.0 percent in business services. The contribution from tangible capital deepening remains approximately the same in all industries. However, the contribution from intermediate inputs deepening decreases considerably in manufacturing from 2.6 to 1.6 percentage points. In business services the corresponding decrease was from 1.3 to 1.1 percentage points.

The contribution of intangible capital deepening is largest in manufacturing with 1.2 percentage points. Thus, 29 percent of labor productivity growth in manufacturing is attributed to intangible investments. In business services intangible capital accounted for 0.5 percentage points or 17 percent of labor productivity growth. The contribution from intangible capital deepening is considerably larger in manufacturing than in business services in both absolute and relative terms.

Table 4 also shows that TFP decreased from 1.4 percentage points to 0.8 in manufacturing when intangible capital was included. In business services the corresponding decrease was from 0.8 to 0.5 percentage points. In total, intangible capital contributed considerably to the high productivity growth both in manufacturing and business services. However, the contribution from intangible capital was larger in manufacturing. Thus, investments in intangibles which often are knowledge intensive services have contributed considerably to productivity growth in manufacturing.

\section{Conclusions}

Since the mid 1990s Sweden has had one of the highest labor productivity growth rates compared to Japan, the US and most other western EU-countries. Productivity growth in manufacturing has been considerably higher than in business services both in absolute figures and relative to the same sectors in other countries. Nevertheless, all employment growth since the mid 1990s has been created in business services. Two potential explanations are Baumol's disease and outsourcing. However, this paper shows that there is an additional explanation: the considerable investments in intangibles in Swedish manufacturing since 1995.

A number of studies have shown that intangibles have become increasingly important in many economies (Corrado et al. 2006; Marrano and Haskel 2006). In Sweden intangible investment 
in the business sector accounted for as much as 10 percent of GDP in 2006. Most intangibles are not capitalized in the National Accounts which means that they are not included in GDP figures. However, calculations based on Edquist (2011) show that if intangible capital was capitalized it would account for nearly 30 percent of labor productivity growth in the Swedish business sector 1995-2006.

This paper investigates intangible investment at the industry level with a specific focus on the differences between manufacturing and services. The results show that intangible investment was 129 billion SEK in manufacturing, while it was 131 billion in the service sector. Thus, the two sectors accounted for almost the same share of intangible investment. However, intangible investment as a share of value added in manufacturing was 25 percent, while the corresponding figure for the service sector was 10 percent. Thus, manufacturing invested considerably more in intangibles relative to its size. Moreover, in comparison to Australia, Japan, the Netherlands and UK, Sweden had the highest share of intangible investment in manufacturing (see figure 5).

The ratio of intangible investment to tangible investment has almost doubled in manufacturing since 1995, while it has stayed the same in business services. This indicates that the importance of intangible investment relative to tangible investment has increased in manufacturing. For business services the increased investment has been equally large in intangible as well as for tangible assets. Thus, there is strong indication of a structural shift in manufacturing production with intangibles becoming increasingly important in manufacturing production.

Results based on growth accounting at the industry level for 5 different industries in the business sector showed that intangible capital deepening accounted for 29 percent of labor productivity growth in manufacturing and 17 percent in business services. Thus, investments in intangibles mostly consisting of knowledge intensive services have been important for productivity growth in Swedish manufacturing in 1995-2006.

The findings in this paper provide an additional explanation to the Swedish productivity and service sector paradox besides Baumol's disease and outsourcing. It is likely that the high productivity growth and rationalization in manufacturing leads to an increasing proportion of the labor force being channeled into the less productive service sector. This results in 
increased relative prices in the service sector as argued by Baumol (1967). Nevertheless, this paper shows that intangible investments, which often are knowledge intensive services have increased in manufacturing since 1995 and also account for a large share of the increased productivity in manufacturing. Thus, investment in services has become increasingly important for productivity growth in manufacturing. When intangible assets are capitalized it becomes evident that the interaction between productive manufacturing and the less productive service sector has increased.

It is also likely that part of the Swedish productivity and service sector paradox is explained by outsourcing. However, it has not been investigated how large impact outsourcing have had on productivity in manufacturing. The results in this paper suggest that intangibles are important for productivity growth in manufacturing. Since estimates of intangibles consist of both a purchased component and an own account component, increased outsourcing could only partly explain the increased investment in intangibles. It is possible that the increase in purchased intangible investment could be explained by increased outsourcing, but the own account component is not affected by outsourcing. Thus, intangible investment provides an additional explanation to the Swedish manufacturing and service sector paradox. 


\section{References}

Affärsvärlden (2001-2004), Konsultguiden, Affärsvärlden, www.afv.se

Barnes, Paula (2010), Investments in Intangible Assets and Australia's Productivity Growth: Sectorial Estimates, Productivity Commission, Melbourne.

Baumol, William (1967), “Macroeconmics of Unbalanced Growth: The Anatomy of Urban Crisis”, American Economic Review, vol. 57, pp. 187-249.

Clayton, Tony, Dal Borgo, Mariela, Haskel, Jonathan (2009), “An Innovation Index Based on Knowledge Capital Investment: Defintion and Results for the UK Market sector”, Working Paper, Imperial Collage, London.

CVTS (1999), Continuing Vocational Training Survey for Sweden, Statistics Sweden, 1999, www.scb.se

Corrado, Carol, Hulten, Charles and Sichel, Daniel (2005), 'Measuring Capital and Technology: An Expanded Framework', In: Corrado, Carol, Haltiwanger, John and Sichel, Daniel (eds), Measuring Capital in the New Economy, National Bureau of Economic Research Studies in Income and Wealth, vol. 65, pp. 11-45, The University of Chicago Press, Chicago and London.

Corrado, Carol, Hulten, Charles and Sichel, Daniel (2006), “The Contribution of Intangible Investments to US Economic Growth: A Sources-of-growth Analysis”, NBER Working Paper. No. 11948.

Corrado, Carol, Hulten, Charles and Sichel, Daniel (2009), “Intangible Capital and U.S. Economic Growth”, Review of Income and Wealth, vol. 55, pp. 661-685.

Edquist, Harald (2011), ”Can Investment in Intangibles Explain the Swedish Productivity Boom in the 1990s?”, Review of Income and Wealth, forthcoming.

Edvinsson, Rodney (2005), Growth, Accumulation, Crisis: With New Macroeconomic Data for Sweden 18002000, Almqvist \& Wiksell International, Stockholm.

EU KLEMS (2008), EU KLEMS Database, March 2008, www.euklems.net

EU KLEMS (2009), EU KLEMS Database, November 2009, www.euklems.net

Frescati Manual (2002), Frescati Manual: Proposed Standard Practice for Surveys on Research and Experimental Development, OECD, Paris.

Fukao, Kyoji, Miyagawa, Tsutomu, Mukai, Kentaro, Shinoda, Yukio and Tonogi, Konomi (2009), "Intangible Investment in Japan: Measurment and Contribution to Economic Growth”, Review of Income and Wealth, vol. 55, pp. 717-736.

Galindo-Rueda, Fernando, Haskel, Jonathan and Pesole, Annarosa (2008), "How much does the UK employ, spend and invest in design?”, CeRiBA Working paper, April.

Hao, Janet X., Manole, Vlad and van Ark, Bart (2009), “Intangible Capital and Growth - an International Comparison”, The Conference Board, September.

Jorgenson, Dale W., Ho, Mun S., Samuels, Jon D. and Stiroh, Kevin J. (2007), “Industry Origins of the American Productivity Resurgence”, Economic System Research, vol. 19, pp. 229-252.

Landes, Elisabeth M. and Andrew M. Rosenfield (1994), “The Durability of Advertising Revisited”, Journal of Industrial Economics, vol. 42, pp. 263-276.

Marrano, Giorgio Mauro and Haskel, Jonathan (2006), “How Much Does the UK Invest in Intangible Assets?”, Working Paper 578, Queen Mary University, London. 
Marrano, Mauro G., Haskel, Jonathan and Wallis, Gavin (2009), "What Happened to the Knowledge Economy? ICT, Intangible Investment and Britain’s Productivity Record Revisited”, Review of Income and Wealth, vol. 55, pp. 686-716.

OECD (2009), ANBERD Database 2005/06, Paris.

OECD (2010), STAN Database, Paris.

van Rooijen-Horsten, Myriam, van den Bergen, Dirk and Tanriseven, Murat (2008), "Intangible capital in the Netherlands: A benchmark”, Discussion paper 08001, Statistics Netherlands.

Solow, Robert (1957), "Technological Change and the Aggregate Production Function”, Review of Economics and Statistics, vol. 39, pp. 65-94.

SOU (2000:11), Finansmarknadsutredningen, Stockholm.

Svensson, Roger (2010), “Outsourcing av producenttjänster”, Ekonomisk Debatt, vol. 38, pp. 43-56.

Statistics Sweden (2010), National Accounts, detailed yearly estimates, 1950-2007, www.scb.se 


\section{Tables and figures}

\subsection{Tables}

Table 1 Business sector spending and investment on intangible assets in Sweden 2006

\begin{tabular}{|c|c|c|c|}
\hline Type of intangible investment & Sources & Investment & $\begin{array}{l}\text { Proportion of spending } \\
\text { considered as investment }\end{array}$ \\
\hline \multicolumn{4}{|l|}{ 1. Computerized information } \\
\hline a) Computer software & EU-KLEMS & 55 & 1 \\
\hline b) Computerized databases & $\begin{array}{l}\text { Included in } \\
\text { computer software }\end{array}$ & n.a & 1 \\
\hline \multicolumn{4}{|l|}{ 2. Innovative property } \\
\hline a) $R \& D$ & OECD ANBERD & 79 & 1 \\
\hline b) Mineral exploration & $\begin{array}{l}\text { SGU (Geological } \\
\text { Survey of Sweden) }\end{array}$ & 0.4 & 1 \\
\hline c) Copyright and license costs & Statistics Sweden & 0.1 & 1 \\
\hline $\begin{array}{l}\text { d) Development costs in } \\
\text { financial industry }\end{array}$ & EU-KLEMS & 4 & 1 \\
\hline e) Design & Statistics Sweden & 36 & 0.5 \\
\hline \multicolumn{4}{|l|}{ 3. Economic competencies } \\
\hline \multicolumn{4}{|l|}{ a) Brand equity } \\
\hline Adverting & $\begin{array}{l}\text { Swedish Institute for } \\
\text { Advertisement } \\
\text { (IRM) }\end{array}$ & 25 & 0.6 \\
\hline Market Research & Statistics Sweden & 3 & 0.6 \\
\hline b) Vocational training & Statistics Sweden & 28 & \\
\hline \multicolumn{4}{|l|}{ c) Organizational structure } \\
\hline Purchased & $\begin{array}{l}\text { Statistics Sweden } \\
\text { and Affärsvärlden }\end{array}$ & 26 & 0.8 \\
\hline Own-account & Statistics Sweden & 15 & 1 \\
\hline Total Spending & & 274 & \\
\hline
\end{tabular}

Sources: "Sources" in table 1 and own calculations. 
Table 2 Investment in intangibles for different industries in 2006 (billion SEK)

\begin{tabular}{lccccc}
\hline Industry & $\begin{array}{l}\text { ISIC } \\
\text { rev 3 }\end{array}$ & $\begin{array}{l}\text { Tangible } \\
\text { investments }\end{array}$ & $\begin{array}{l}\text { Intangible } \\
\text { investments }\end{array}$ & $\begin{array}{l}\text { Percent of } \\
\text { total } \\
\text { tangible } \\
\text { investment }\end{array}$ & $\begin{array}{l}\text { Percent of } \\
\text { total } \\
\text { intangible } \\
\text { investment }\end{array}$ \\
\hline Mining & $10-14$ & 6 & 1 & 2 & 0.4 \\
Manufacturing & $15-37$ & 63 & 129 & 17 & 47 \\
$\begin{array}{l}\text { Electricity } \\
\text { Construction }\end{array}$ & $40-41$ & 38 & 5 & 10 & 2 \\
Business services & 45 & 17 & 6 & 4 & 2 \\
& $50-74$ & 253 & 131 & 67 & 48 \\
\hline $\begin{array}{l}\text { Total non-farm business } \\
\text { sector }\end{array}$ & $\mathbf{1 0 - 7 4}$ & $\mathbf{3 7 6}$ & $\mathbf{2 7 4}$ & $\mathbf{1 0 0}$ & $\mathbf{1 0 0}$ \\
\hline
\end{tabular}

Sources: Sources listed in table 1 and Statisics Sweden (2010).

Note: Software and copyright and license costs have been excluded from tangible investment figures. 
Table 3 Growth accounting at the sector level excluding software in 2000-2006

\begin{tabular}{|l|c|c|c|c|c|c|c|}
\hline & $\begin{array}{c}\text { Gross } \\
\text { output }\end{array}$ & $\begin{array}{c}\text { Hours } \\
\text { worked }\end{array}$ & LP & Capital deepening & $\begin{array}{c}\text { Intermediate input } \\
\text { deepening }\end{array}$ & Labor quality & TFP \\
\hline Mining & -0.26 & -0.87 & 0.62 & 1.66 & 2.19 & 0.04 & -3.28 \\
\hline Manufacturing & 3.16 & -1.39 & 4.55 & 0.43 & 2.63 & 0.12 & 1.36 \\
\hline Electricity, gas and water & 0.36 & 0.55 & -0.19 & 0.59 & 0.49 & 0.05 & -1.32 \\
\hline Construction & 2.81 & 1.50 & 1.31 & 0.17 & 0.95 & 0.09 & 0.10 \\
\hline Business services & 3.51 & 0.51 & 3.00 & 0.67 & 1.34 & 0.20 & 0.79 \\
\hline
\end{tabular}

Sources: EU KLEMS (2009) and own calculations.

Table 4 Growth accounting at the sector level including intangible investment in 2000-2006

\begin{tabular}{|c|c|c|c|c|c|c|c|c|}
\hline & \multirow{2}{*}{$\begin{array}{l}\text { Gross } \\
\text { output }\end{array}$} & \multirow{2}{*}{$\begin{array}{c}\text { Hours } \\
\text { worked }\end{array}$} & \multirow[t]{2}{*}{ LP } & \multicolumn{2}{|c|}{ Capital deepening } & \multirow{2}{*}{$\begin{array}{c}\text { Intermediate } \\
\text { input } \\
\text { deepening }\end{array}$} & \multirow[t]{2}{*}{ Labor quality } & \multirow[t]{2}{*}{ TFP } \\
\hline & & & & $\begin{array}{c}\text { Tangible } \\
\text { capital }\end{array}$ & $\begin{array}{c}\text { Intangible } \\
\text { capital }\end{array}$ & & & \\
\hline Mining & -0.27 & -0.87 & 0.60 & 1.72 & 0.11 & 2.43 & 0.04 & -3.68 \\
\hline Manufacturing & 2.81 & -1.39 & 4.20 & 0.43 & 1.22 & 1.63 & 0.12 & 0.79 \\
\hline Electricity, gas and water & 0.36 & 0.55 & -0.19 & 0.60 & 0.27 & 0.52 & 0.05 & -1.63 \\
\hline Construction & 2.81 & 1.50 & 1.31 & 0.20 & 0.11 & 0.98 & 0.09 & -0.07 \\
\hline Business services & 3.53 & 0.51 & 3.02 & 0.72 & 0.51 & 1.07 & 0.20 & 0.52 \\
\hline
\end{tabular}

Sources: EU KLEMS (2009) and own calculations. 


\subsection{Figures}

Figure 1 Annual labor productivity growth in manufacturing and business services in Japan, the US and EU-15, 1995-2007.

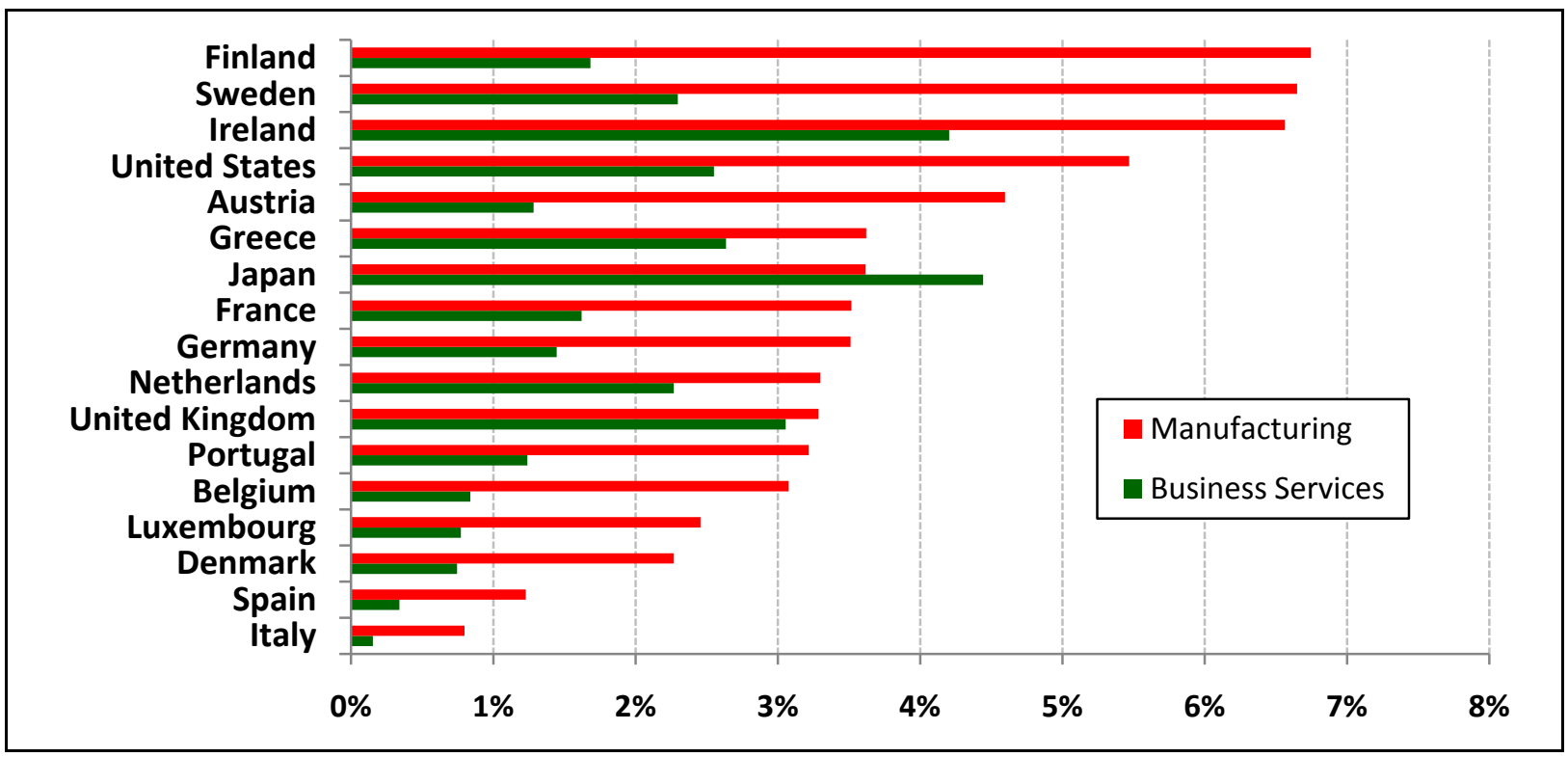

Note: Manufacturing is defined as ISIC 15-37 and business services as ISIC 50-74.

Sources: EU KLEMS (2009), OECD (2010) and own calculations.

Figure 2 Business sector spending and investment in intangible capital and physical capital in Sweden (percent of GDP)

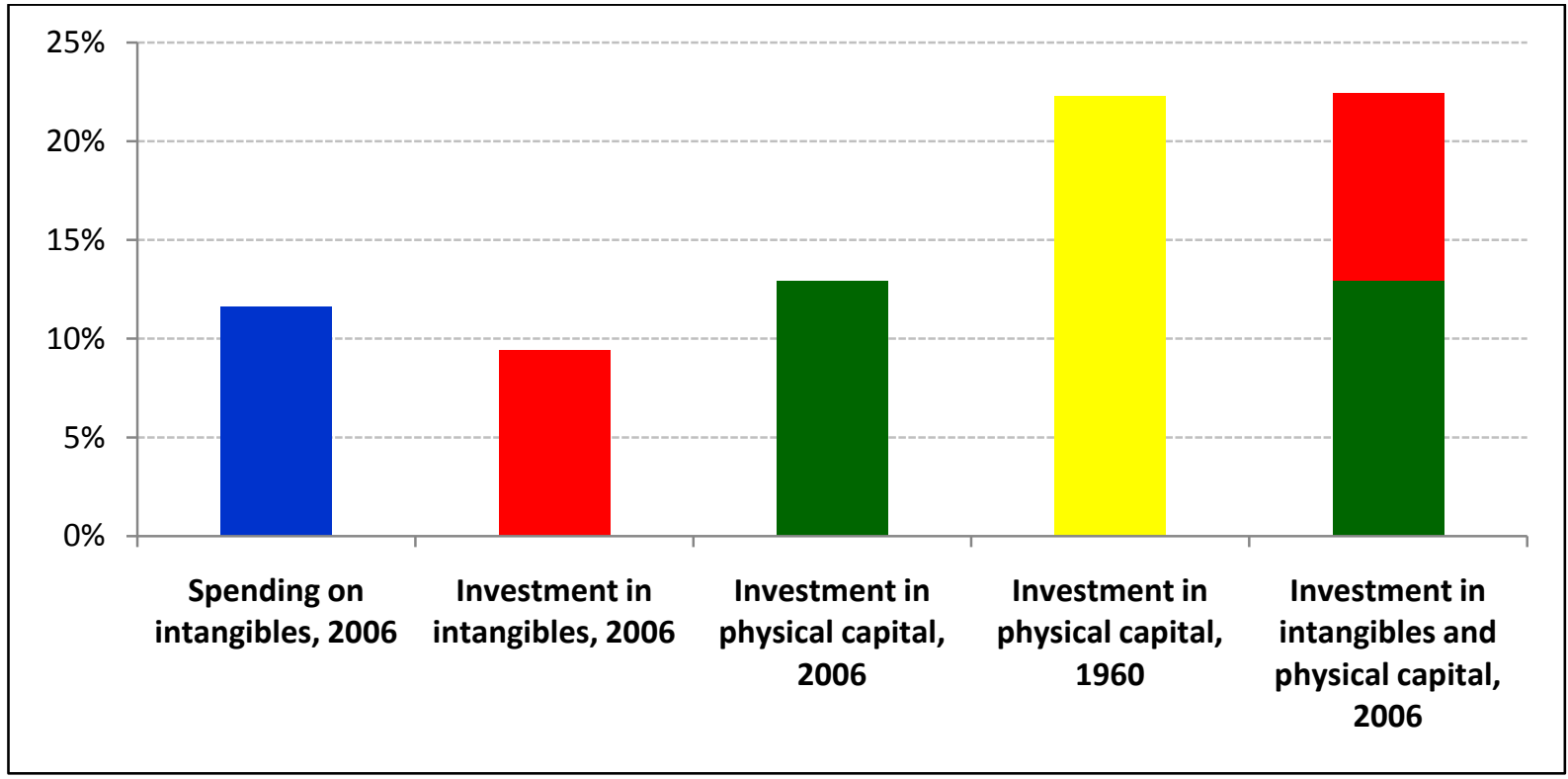

Note: Copyright and license cost and software are excluded in physical capital. GDP is conventionally measured i.e. including software and copyright but excluding other intangibles. 
Sources: Statistics Sweden (2010), Edvinsson (2005) and own calculations.

Figure 3 Ratio of intangible to tangible investment in Swedish manufacturing and business services 1995-2006

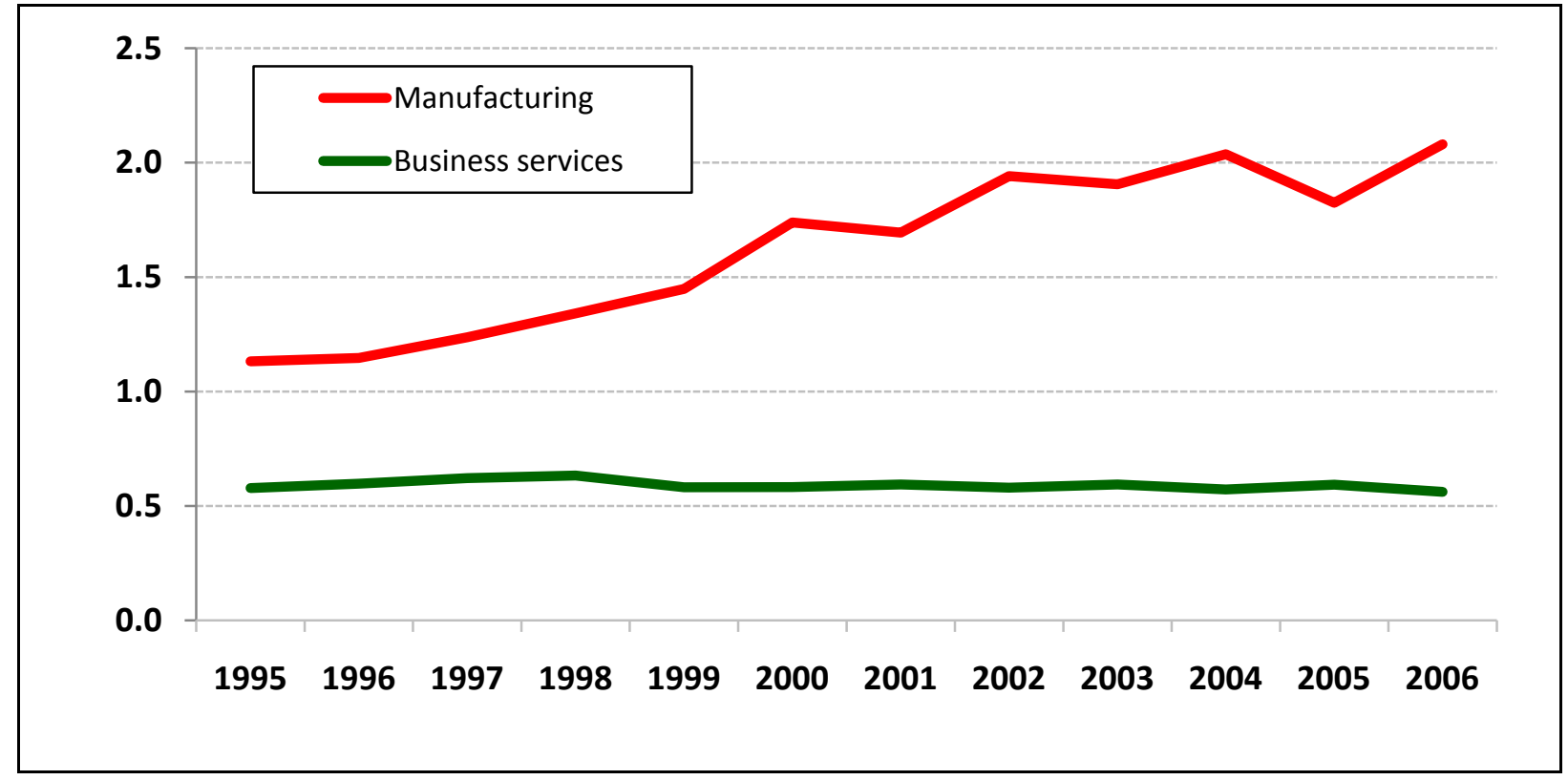

Sources: Statistics Sweden (2010) and own calculations.

Figure 4 Investment for different categories of intangible assets in the Swedish business sector 2006

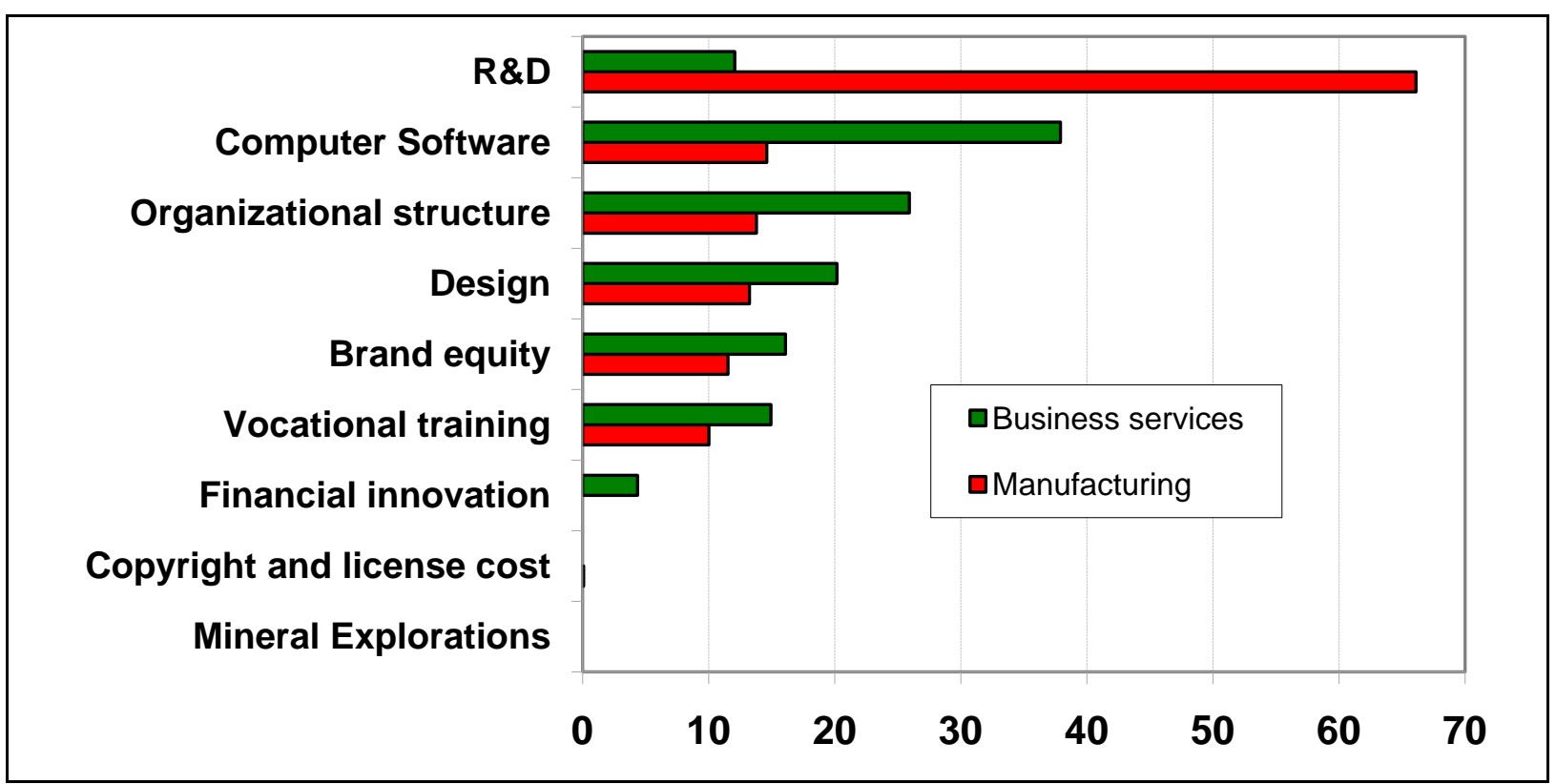

Sources: Sources listed in table 1 and own calculations. 
Figure 5 Intangible investments in manufacturing and business services in five different countries 2000-2006 (percent of value added in each sector)

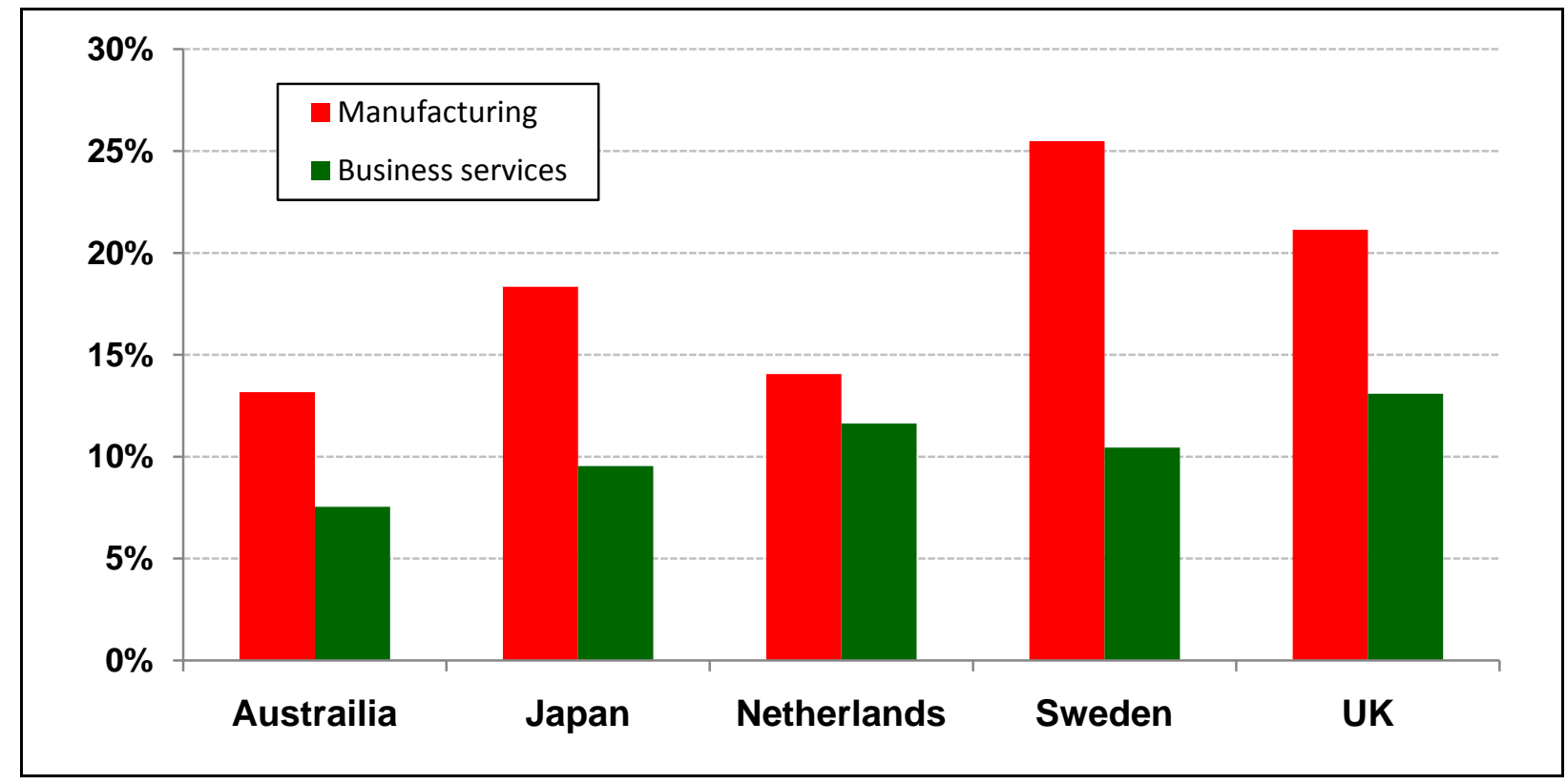

Note: The data for each country is for the following periods: Australia 2005-2006; Japan 2000-2005; Netherlands 2004; Sweden 2005-2006; United Kingdom 2005.

Sources: Barnes (2010), Clayton et al. (2009), Fukao et al. (2009), van Rooijen-Horsten, van den Bergen och Tanriseven (2008) and own calculations.

Figure 6 Labor productivity growth accounting results for the business sector in Sweden 1995-2006 (percentage points)

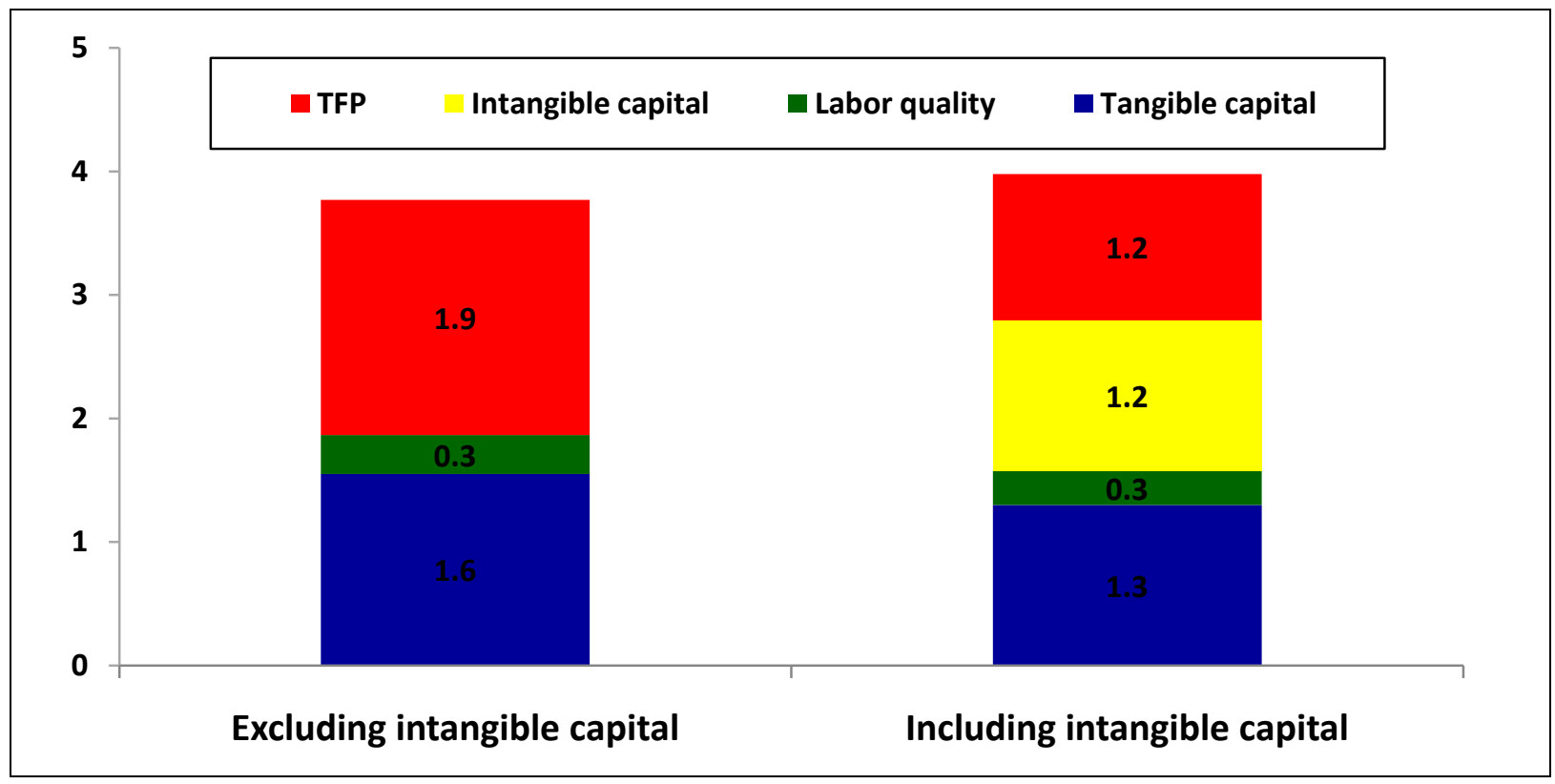

Sources: EU KLEMS (2008; 2009), sources listed in table 1 and own calculations. 